\title{
EFL College Students' Perceptions of Classroom English Tests
}

\author{
Nowreyah A. Al-Nouh ${ }^{1}$, Muneera M. Abdul-Kareem ${ }^{2} \&$ Hanan A. Taqi ${ }^{1}$ \\ ${ }^{1}$ English Department, College of Basic Education, Kuwait City, Kuwait \\ ${ }^{2}$ College of Education, Kuwait University, Kuwait City, Kuwait \\ Correspondence: Nowreyah Al-Nouh, English Department, College of Basic Education, Al-Ardhiya, Block 1, Str. \\ Mohammed Ibn Al-Qasim, facing Jaber Stadium, Kuwait City, Kuwait. Tel: 965-99-112-672. E-mail: \\ nowreyah2008@hotmail.com
}

Received: November 18, 2013

Accepted: December 10, 2013 Online Published: December 12, 2013

doi:10.5430/ijhe.v3n1p71

URL: http://dx.doi.org/10.5430/ijhe.v3n1p71

\begin{abstract}
Students' perceptions of their classroom English tests play a crucial role in affecting their performance. Hence, the present study is interested in soliciting college students' perceptions of their classroom English tests to find out the reasons behind test difficulties. Participants were 585 female college students chosen randomly from all grade levels enrolled in a four years pre-service teacher education program at the CBE in Kuwait. The study employed a descriptive survey research design using Likert's five-point scale distributed into three categories: Linguistic reasons, psychological reasons and other reasons. Independent variables measured were age, grade level, nationality and GPA. Results revealed students' perceptions were at a medium level. Significant differences were found for nationality and GPA. Implications for ways of conducting classroom English tests as well as recommendations for future research were discussed.
\end{abstract}

Keywords: Classroom test, Student perception, English test, College student perception

\section{Introduction}

Researchers, policy makers and educationalists have been interested in finding out about students' difficulties in learning a foreign language as a step towards enhancing students' performance on tests. Some questioned teachers' proficiency and teachers' practice and proposed in-service training (Ho, 2008); others examined tests and questioned their validity (Shi \& He, 2012).

Still, others were interested in finding out about factors that cause low performance on tests (Fillipi, 2012). Most of those studies reported anxiety as one of the main factors causing bad performance on tests (Coulombe, 2000; Kim, 2000; Birjandi \& Alemi, 2010; Ya-Chin \& Yi-Chih, 2012). A number of those studies addressed anxiety in general while others emphasized test anxiety. Specifically, most of those studies focused on standardized tests rather than classroom tests (Korhonen, Linnanmaki, \& Aunio, 2011). Additionally, most of the studies were done on ESL students (Teemant, 2010), while a few were interested in EFL students. Overall, research on English as a foreign language (EFL) students' difficulties with English tests is scant (Zeidner \& Bensoussan, 1988; Murray, Riazi, \& Cross, 2012). As Teemant (2010) pointed out, the gap between students' actual knowledge and their test performance is often ignored.

To investigate the difficulties that students might face during classroom tests in general and English tests in particular will help improving students' performance. Also, soliciting students' own perceptions of the difficulties they face during classroom English tests will provide more valid data. Hence, the present study is interested in soliciting College of Basic Education (CBE) students' perceptions of the reasons behind the difficulties in their classroom English tests. Lack of language proficiency, according to Li, Baker and Marshall (2002:1) is one of the main reasons international students experience a mismatch between expectations and experiences. Since language proficiency is a prerequisite for academic success, the present study intends to explore linguistic, psychological and other factors that might cause difficulty for EFL students, with emphasis on linguistic factors.

\section{The Educational Background}

The Public Authority for Applied Education and Training (PAAET) in Kuwait was established in 1985. Since then, it has gone through a number of developments. In February 2002 the English Department introduced a new program at the College of Basic Education for the degree of B.Ed. in English. This program lasts for four years and is aimed to provide the Ministry of Education in Kuwait with qualified primary school English teachers. For students to graduate, 
they need to complete 130 Credit Hours. The English Major consist of 60 Credit Hours of which 12 credits for the Basic Language Skills, 21 credits for Theoretical and Applied Linguistics, 12 credits for Literature and 15 credits for English as a Foreign/Second Language. Added to that, students have to take two French courses in partial fulfillment of the General Education Requirements. To be admitted to the English Department, students need to be high school graduates and need to pass an Admission Test prepared by the department. After taking the placement test, students need to be interviewed.

In 1975 the College of Business Studies was built. The English Department in the College was responsible for all English courses offered at the four colleges namely, College of Basic Education (CBE), College of Business Studies (CBS), College of Technological Studies (CTS), and College of Health Sciences (CHS). The College of Nursing was not established then. The courses offered then were General English (GE) and English for Specific Purposes (ESP).

When the English Major was introduced at the CBE, the department of English moved from CBS to CBE. Still, the CBS continued to be responsible for teaching English at the other three colleges.

In 2007, a language center was established under the supervision of the CBS. It became responsible for teaching English at all the colleges (boys \& girls) including the CBE. This made the English Department at the CBE responsible only for the English Major Program introduced at the Girls Campus at the CBE.

\section{Statement of the Problem}

In Kuwait, foreign language learning starts at primary stage where students spend five years learning English followed by four years at intermediate stage and three more years at secondary. From my experience as a teacher, I noticed that students' main objective is to pass tests to get a degree and join college. Once students enter college, they find it difficult to cope with academic language used. Furthermore, they are required to understand and respond to academic language in tests. During tests, teachers focus on vocabulary, spelling and grammar mistakes as well as coherence and cohesion. Students find themselves at a disadvantage, so they memorize everything and the result is usually bad performance on tests. Hence, teachers and policy makers complain of students' low performance on tests (Malallah, 2000; Al-Mutawa, 1996; Zheng, 2002; Al-Nemshan, 2013; Abidin, 2012). Thus, the present study intends to discuss the factors that are believed to cause students' bad performance on tests.

\section{Literature Review}

Learning a language that is not one's first language is not easy. The literature has shown how students strive to learn a second language (SL) (Kanwal \& Khurshid, 2012; Al-Nemshan, 2013 ;). Learning a foreign language (FL) is even harder when students practice the foreign language (i.e. English) as a school subject for a few minutes a day for a few days a week. It is even harder when the teacher is a non-native speaker (NNS) who speaks the students' first language (L1). Added to that is the fact that teachers teach to the test which is limited in scope to what is in the textbook and depends on memorization (Jenkins, 2000; Cheung, 2012).

Researchers and educationalists have been trying to find out why learners perform badly on tests. Some focused on standardized tests like TOEFL (Test of English as a Foreign Language) and IELTS (International English Language Testing System) (Wait \& Gressel, 2009; Aboudan, 2011; Wolf \& Steinberg, 2011). However, students apply for these tests when they want to study abroad while classroom tests are given at frequent intervals and are accurate indications of students' level. This is substantiated by Xu (1991) who stated that the TOEFL is a test of speed rather than proficiency.

The literature has examined the factors that cause bad performance on tests. These factors can be grouped under three main categories: psychological factors, linguistic factors, and other factors. First, psychological factors are those related to feelings and thoughts like anxiety, fear of failure, lack of self-confidence, worry and nervousness. For example, Greene (1929) found that students' feelings of whether a test is easy or difficult affect their performance. Test anxiety is considered one of the main factors causing bad performance on tests (Aydn, Yavuz, \& Yesilyurts, 2006; Birjandi \& Alemi, 2010; Aydin, 2011; Ya-Chin \& Yi-Chih, 2012). In Iran, for instance, Birjandi and Alemi (2010) aimed at finding out the reasons behind test-taking anxiety. They found out that students' familiarity with multiple-choice tests in secondary school reduced their test anxiety. In addition, Aydn et al. (2006) examined the test anxiety level of Turkish EFL university students and its effects on FL learning. They concluded that learners usually have test anxiety for many reasons, such as low level proficiency, students' attitudes towards language learning, fear of negative evaluations, bad experiences on tests, test invalidity, pressure and difficulty of course content. Moreover, they found out that test anxiety results in physical and psychological problems, which affect concentration and achievement and increase errors in learning.

It is interesting to note that age has an effect on the level of test anxiety. For example, a study by Aydin (2011) aimed to investigate the relationship between test anxiety of young EFL learners and their perceptions of content validity, 
test technique and clarity of test instructions found that students felt confident and relaxed about tests. He concluded that anxiety seems to be more related to adults than young learners.

Other studies looked at the effect of students' expectations on their performance on tests. For example, Sweiry, Crisp, Ahmed, \& Pollitt (2002) wanted to find out whether students' expectations influence their performance. They noted that students' experiences of classroom tests create a schema which will be activated once sitting for a test and lead to interpreting questions in a way not intended by the examiner. They concluded that expectations influence performance on tests (Onwuegbuzie, Baiey, \& Daley, 2001).

Second, linguistic factors are those related to linguistic competence, including knowledge of vocabulary and grammar. Studies have shown that English proficiency affects students' performance on tests (Aydn et al., 2006; Teemant, 2010; Korhonen et al., 2012). For example, in New York, Xu (1991) examined the effect of English proficiency on the level of academic difficulties of international graduate students and found out that students self-rated 'English proficiency' as a predictor of the perceived level of Academic difficulty. Similarly, to investigate English as a Second Language (ESL) university students' perceptions of English language learning needs in Australia, Ransom, Larcombe, \& Baik (2006) pointed out that students believed their current English language skills are inadequate and suggested additional language development courses in writing.

In an empirical study to find out the effect of the language of the question on students' performance, Filipi (2012) concluded that the language in which an item is written may be one factor in determining item difficulty and the test format being another factor. Essay questions or completion, for example, placed more demands on students' cognition as students have to memorize information, organize it and check spelling and grammar while in multiple-choice items information is explicitly stated. Also, redundancy, where vocabulary words are repeated in the stem and in the multiple choice items, makes items less difficult. Fisher-Hoch, Hughes and Bramley (1997:1) differentiated between 'valid difficulty' where the student is unable to recall information to answer the question and 'invalid difficulty' where the student can not recall the information because of the language of the question.

Knowledge of vocabulary is important in determining item difficulty. In Sweden, for example, Korhonen et al. (2012) investigated whether there was a connection between language and mathematical performance and found out that students with low mathematical performance had low scores in vocabulary, reading comprehension and spelling.

More language problems are reported by Teemant (2010) who studied problems in testing and found out that vocabulary and grammar were one of the main problems. Other problems were the inability to read, lack of vocabulary both receptive and productive, poor word choice, the inability to understand questions and memorize in English and lack of knowledge on how to write (Al-Buainain, 2006). He suggested that for some students words may impede comprehension rather than show knowledge of content.

Similarly, Harrison and Morgan (2012) aimed to find out the effect of using simplified English to identify difficulties in the language of examinations and concluded that there are benefits of simplified English such as using familiar vocabulary, rewording, using simple sentence structure and clear test instructions.

In a similar study, in California, the Institute of Education Sciences (ies) (2012) set to assess the effect of linguistic adjustment on a standardized Math achievement test. Results showed a positive effect on Math scores for students struggling with English who completed the modified test. Similarly, Bird and Welford (1995) wanted to explore the effect of using both modified and unmodified tests on native and non-native speakers and found differences between the two tests with non-native speakers.

Other factors that affect students' performance on tests are reported by Teemant (2010) who wanted to find out ESL university students' problems in testing. He found that students do not know how to express their opinions, memorize in English, paraphrase, or read questions (Birjandi \& Alemi, 2010; Murray, 2010; Harrison \& Morgan, 2012). Other factors include knowledge of how to prepare for tests, the testing environment, the time allowed for the test, the test format and length, relevance of test content to what students studied, test design, and parental expectations. Added to that, students burden themselves with courses and end up not having time to study. This is substantiated by Drew (2001) and others who argued that studying for more than one subject affects the depth of what is studied (Zeidner \& Bensoussan, 1988; Jing, 2005; Crisp, Sweiry, Ahmed, \& Pollitt 2008; Teemant, 2010; Aydin, 2012).

Although previous research discussed factors that affect students' achievement on tests, those studies are limited in scope. Most of the previous studies were done on ESL rather than EFL learners. According to Aydin (2012) it is not possible to perceive that second and foreign language contexts are the same. Therefore, results of studies done on ESL learners can not be generalized to EFL learners. Also, most of the studies were done on children and adolescents; only a few were done on adults. Additionally, most studies investigated standardized or international tests rather than local classroom tests. Also, a big number of those studies were interested in exploring anxiety with emphasis on test 
anxiety and factors that affect performance on tests in general. With those factors in mind, the present study intends to focus on linguistic factors. Surprisingly, little is known about EFL students. Also, very little research has been carried out to date with respect to the perceptions of examinees.

Exploring the dominant factors behind college students' low performance on EFL classroom tests will help learners come to terms with difficulties and constraints in EFL learning. It will provide valuable data that would help in understanding students' learning. It should be given due consideration and weight by instructors who seek to improve their practice. It is a potentially valuable but neglected source of information about EFL classroom tests. Also, the literature on attitudes of candidates to tests is much more limited (Murray et al., 2012). Taking students' point of view into consideration, instructors may perceive problematic areas in EFL testing. Consequently, perceived problems in the test can be dealt with properly. Students change, so do their perceptions, hence the need for an ongoing research on students' perceptions to add to the limited amount of research and contribute greatly to the understanding of the factors that might hinder learning English in a foreign language context. With these concerns in mind, the present study aims to solicit EFL college students' perceptions of classroom English tests. The research questions guiding this study are as follows:

1. What are the overall college EFL students' perceptions of their performance on classroom English exams?

2. Are there significant differences between college EFL students' perceptions in terms of age?

3. Are there significant differences between college EFL students' perceptions in terms of grade level?

4. Are there significant differences between college EFL students' perceptions in terms of nationality?

5. Are there significant differences between college EFL students' perceptions in terms of GPA?

6. Which of the following factors: linguistic, psychological, or other affect college EFL students' performance the most?

\section{Method}

\subsection{Subjects}

Five hundred and eighty five (585) female college EFL students from all grade levels enrolled in a four-year (TEYLS) program at CBE in Kuwait participated in the study during the winter semester 2012-2013. Of the 585 students who participated in the study, 570 returned completed questionnaires. Four hundred twenty six (74.7\%) of the participants were Kuwaiti and $139(24.4 \%)$ were non-Kuwaiti. The overwhelming majority of respondents i.e. $80 \%$ are in the $-18 / 22$ age group, compared with $20 \%$ in the $23+$ age group (Table 1 ).

Table 1. Distribution of Sample

\begin{tabular}{lll}
\hline Independent Variables & No. & $\%$ \\
\hline Grade Level & & \\
First Grade & 162 & 28.4 \\
Second grade & 188 & 33.0 \\
Third grade & 143 & 25.1 \\
Fourth grade & 77 & 13.5 \\
Total & 570 & $100 \%$ \\
Age* & & \\
22 and less & 453 & 80.0 \\
23 and more & 113 & 20.0 \\
Total & 566 & 100.0 \\
Nationality* & & \\
Kuwaiti & 426 & 75.4 \\
Non- kuwaiti & 139 & 24.6 \\
Total & 565 & 100 \\
General G.P.A* & & \\
3.67 and more & 43 & 7.9 \\
$3.66-2.67$ & 228 & 42.1 \\
2.66-1.67 & 202 & 37.3 \\
1.66 and less & 68 & 12.6 \\
Total & 541 & 100 \\
\hline
\end{tabular}

*Variables where a few subjects did not provide their age, nationality or GPA; therefore, they were not counted during the tests of variables 


\subsection{Instrument}

A questionnaire was developed to obtain information about EFL college students' perceptions of their performance on classroom English tests. The questionnaire items were taken mostly from the literature (see e.g. Sarason, 1978; Crisp et al., 2008; Birjandi \& Alemi, 2010; Teemant, 2010; Aydin, 2012). Another source was asking a group of students to write down about the difficulties they usually have during classroom English tests. Students' feedback was used in writing the final questionnaire. The questionnaire is comprised of four sections: the first section asked participants about their 'demographic information' such as age, grade level, nationality and GPA. The second section asked about 'linguistics factors' that affect students' performance on tests and is comprised of 22 items. The third section focused on 'psychological factors' and consisted of 10 items. The last section included the 'other factors' and is comprised of 13 items. In addition, students were asked to answer an open-ended question at the end of the questionnaire about other reasons for the difficulties in classroom English tests.

In order to achieve consistency, the draft of the tool was submitted to a number of referees. Consequently the questionnaire was modified based on their comments were some items where rewritten for the sake of clarification.

A 5-point Likert scale was used to assess students' perceptions. Each item was assessed on a scale from 1 to 5 $($ Never $=1$, Rarely $=2$, Sometimes $=3$, Often $=4$, Always $=5)$. A Cronbach Alpha reliability coefficient of 0.913 has been reported indicating a high level of reliability of the scale.

\subsection{Procedure}

The revised version of the questionnaire was piloted on 30 students to check comprehension and clarity of the items. As a result, some modifications were made for more clarity and precession. The final questionnaire was distributed during the winter semester of the academic year 2012/2013 and was filled out by the remaining 570 students.

\section{Statistical Analysis}

Descriptive statistics was used to compare the basic features of the data. First, frequencies, percentages, Means and Standard Deviations were used to describe students' perceptions of the reasons behind difficulties in classroom English tests in relation to three factors: 'linguistic', 'psychological' and 'other'. Second, a t-test for significant differences was employed to compare between the two age groups and between the Kuwaiti and non-Kuwaiti groups in linguistic, psychological and other factors. Third, an ANOVA test for significant differences was used to compare between the four grade-level groups and the four GPA level groups in linguistic, psychological and other factors.

For statistical analysis, participants' perceptions were categorized into three levels: high, medium and low. For example, the high value in Likert scale (i.e. 5.00) is subtracted from the low value (i.e. 1.00) and divided by the three levels.

$$
\begin{array}{ll}
\text { - } & 1.00+1.33=2.33 \\
\text { - } & 2.33+1.33=3.66 \\
\text { - } & 3.66+1.33=5.00
\end{array}
$$

Based on the above, means are calculated as follows:

$$
\begin{array}{lll}
\text { - } & (\text { From } 1-2.33) & \text { indicates a low value mean } \\
\text { - } & (\text { From } 2.34-3.66) & \text { indicates a medium value mean } \\
& (\text { From } 3.67-5.00) & \text { indicates a high value mean }
\end{array}
$$

Regarding the open-ended question posed at the end of the questionnaire, 150 students reported different reasons from those proposed in the study for difficulties on classroom English tests while the rest confirmed the aforementioned reasons. Consequently, after reviewing the data to allow dominant themes to appear, five themes came up. To interpret the data, the author conducted content analysis by grouping students' responses into categories.

\section{Results \& Discussion}

In response to the first research question posed elsewhere in the study, the findings in Table 2 show that the overall perceptions of EFL female college students of their performance on classroom English tests reflect medium difficulty regarding the three factors, namely Linguistic, psychological and other. 
Table 2. General Means and Standard Deviations for all the Factors

\begin{tabular}{lllll}
\hline Title & Mean & SD & Rank \\
\hline 1. & Linguistic Factor & 2.90 & 0.60 & Medium \\
2. & Psychological Factor & 2.91 & 0.69 & Medium \\
3. & Other factors & 3.22 & 0.77 & Medium \\
\hline
\end{tabular}

The means and standard deviations for the factors are shown in Table 2.

Although the overall perceptions of students towards linguistic factors show a medium level $(\mathrm{M}=2.90)$, Table 3 shows that a large number of students believed that their weakness in grammar is one of the difficulties they 'sometimes' come across in English tests. However, more than half of the students reported that they do not have a problem in reading and understanding test questions $(\mathrm{M}=2.23)$. This is inconsistent with Teemant (2010) where students reported a need for improving their reading skills and Saito, Horwitz and Garza (1999) who found that some American learners of French, Russian and Japanese felt anxious when asked to read in the target language. Similarly, they did not seem to have a problem with English vocabulary as more than half of them said they 'sometimes' have a problem with English words and terminology when it comes to memorization, answering and understanding test questions. On the contrary, in Jing's study, (2005) students reported limited vocabulary as a problem. The inconsistency in results might be justified by the fact that students in the present study depend on rote memorization. However, most students believed that they 'always' need to know how the questions are formed in the test $(M=3.67)$. This is consistent with Teemant's study (2010) who found that test format is one of three factors affecting students' performance on tests, namely language proficiency and test anxiety. It is argued that students build schemas about how questions are usually formed which causes them to expect certain kinds of questions and to answer in a certain way. Not only that, but a new test format may cause students to perform poorly (Crisp et al., 2008; Aydin, 2012).

Table 3. Means and Standard Deviations of Students' Perceptions to Linguistic Factors

\begin{tabular}{|c|c|c|c|c|}
\hline & Statement & Mean & SD & Rank \\
\hline 1. & $\begin{array}{l}\text { Because I'm weak in grammar, I } \\
\text { get low grades in the exam. }\end{array}$ & 3.14 & 1.09 & Medium \\
\hline 2. & $\begin{array}{l}\text { Because I'm weak in reading, I } \\
\text { misunderstand the question. }\end{array}$ & 2.23 & 1.11 & Low \\
\hline 3. & $\begin{array}{l}\text { Because of difficult vocabulary, I } \\
\text { can't memorize information. }\end{array}$ & 2.71 & 1.11 & Medium \\
\hline 4. & $\begin{array}{l}\text { Because of unknown words, I } \\
\text { hesitate to answer the question. }\end{array}$ & 2.82 & 1.134 & Medium \\
\hline 5. & $\begin{array}{l}\text { Because I don't know enough } \\
\text { synonyms, I misunderstand the } \\
\text { question. }\end{array}$ & 3.06 & 1.07 & Medium \\
\hline 6. & $\begin{array}{l}\text { I need to know the format of the } \\
\text { question before the exam. }\end{array}$ & 3.67 & 1.24 & High \\
\hline 7. & $\begin{array}{l}\text { In exams, I think in Arabic then } \\
\text { translate to English in writing. }\end{array}$ & 2.76 & 1.30 & Medium \\
\hline
\end{tabular}

The means and standard deviations of students' perceptions to linguistic factors are shown in Table 3.

As for Table 4, the means reflect medium level of perceptions. However, statements 9 and 10 show students' concern, to some extent, about their vocabulary knowledge. This might be the result of using traditional testing approaches in secondary school that depend on memorization and doesn't compare to their English major courses. Another concern shows in students' dependence on memorizing the question, once it is different, they can't answer it. Similarly, grammar and spelling mistakes cause difficulty to students. This is supported by Teemant's study (2010) who reported that students disliked essay questions because of their weakness in spelling and grammar. This might be the result of a long history of memorization where teachers help students memorize questions and answers to pass tests. Teachers are concerned about students' test scores as teachers are evaluated on their students' performance on tests and parents are concerned about their children's test scores to be able to join college and get a job. 
Table 4. Means and Standard Deviations of Students' Perceptions to Linguistic Factors

\begin{tabular}{|c|c|c|c|c|}
\hline & Statement & Mean & SD & Rank \\
\hline 8. & $\begin{array}{l}\text { In true and false questions, I } \\
\text { miss words like no, only, a few. }\end{array}$ & 2.60 & 1.12 & Medium \\
\hline 9. & $\begin{array}{l}\text { I understand the question but } \\
\text { find it difficult to find the right } \\
\text { words to answer it. }\end{array}$ & 3.02 & 1.12 & Medium \\
\hline 10. & $\begin{array}{l}\text { My vocabulary does not help me } \\
\text { during exams. }\end{array}$ & 2.74 & 0.94 & Medium \\
\hline 11. & $\begin{array}{l}\text { I need someone to explain the } \\
\text { question during the exam. }\end{array}$ & 2.73 & 1.19 & Medium \\
\hline 12. & $\begin{array}{l}\text { I don't understand the question } \\
\text { when it is written differently } \\
\text { from the book. }\end{array}$ & 2.77 & 1.16 & Medium \\
\hline 13. & $\begin{array}{l}\text { I don't know how to apply } \\
\text { grammar rules during exams, } \\
\text { although I know them. }\end{array}$ & 2.84 & 1.19 & Medium \\
\hline 14. & $\begin{array}{l}\text { I make grammar and spelling } \\
\text { mistakes when answering } \\
\text { open-ended questions. }\end{array}$ & 3.22 & 1.07 & Medium \\
\hline
\end{tabular}

Means and standard deviations of students' perceptions to linguistic factors are shown in Table 4.

What is more, some students believe that some of the English courses offered at the department do not suit their linguistic abilities (see Table 5). Students further acknowledged their linguistic mistakes as a difficulty preventing them, sometimes, from free expression. They showed concern regarding memorizing and remembering information exactly like the book. Similarly, Teemant (2010) reported some students finding memorization hard. This is the result of teachers expecting to see the same wording with that in the set book. This might explain why students did not always have a problem with vocabulary and 'rarely' had a problem with reading. In Paris's (2000) study, many teachers reported teaching students the kind of vocabulary used in tests by providing them with last year tests for practice.

Table 5. Means and Standard Deviations of Students' Perceptions to Linguistic Factors

\begin{tabular}{|c|c|c|c|c|}
\hline & Statement & Mean & SD & Rank \\
\hline 15. & $\begin{array}{l}\text { English courses do not suit } \\
\text { students' linguistic skills. }\end{array}$ & 2.86 & 1.10 & Medium \\
\hline 16. & $\begin{array}{l}\text { English courses do not suit } \\
\text { students' thinking skills. }\end{array}$ & 2.86 & 1.10 & Medium \\
\hline 17. & $\begin{array}{l}\text { All English courses do not suit } \\
\text { students' abilities. }\end{array}$ & 3.13 & 1.10 & Medium \\
\hline 18. & $\begin{array}{l}\text { I make my answer brief of fear } \\
\text { of linguistic errors which affects } \\
\text { the answer. }\end{array}$ & 3.02 & 1.17 & Medium \\
\hline 19. & $\begin{array}{l}\text { I don't read the question } \\
\text { carefully, so I miss part of it. }\end{array}$ & 2.33 & 1.18 & Low \\
\hline 20. & $\begin{array}{l}\text { I find it difficult to memorize the } \\
\text { answer exactly like the book. }\end{array}$ & 3.22 & 1.27 & Medium \\
\hline 21. & $\begin{array}{l}\text { I find it difficult to remember the } \\
\text { exact answer from the book. }\end{array}$ & 3.38 & 1.18 & Medium \\
\hline 22. & $\begin{array}{l}\text { I find it difficult to understand } \\
\text { the question, although I know } \\
\text { the answer. }\end{array}$ & 2.75 & 1.17 & Medium \\
\hline
\end{tabular}

Means and standard deviations of students' perceptions to linguistic factors are shown in Table 5. 
Regarding perceptions of students towards 'psychological factors', students overall perceptions show a medium level $(\mathrm{M}=2.91)$ (see Table 2). Most students reported that fear of the test 'always' affects their performance in the test. This is consistent with Aydn et al. (2006) who used a test anxiety scale on 114 Turkish university students and found that students usually have test anxiety. According to Ya-Chin and Yi-Chih (2012) anxious people know the answer but 'freeze up' biologically during tests unable to demonstrate the information they learned. It is believed that this is a natural human behavior, but might cause some people to panic and forget. Other things like thinking of others, getting distracted, forgetting information and feeling nervous after the test did not seem to bother students much.

Table 6. Means and Standard Deviations of Students' Perceptions to Psychological Factors

\begin{tabular}{llll}
\hline \multicolumn{1}{c}{ Statement } & Mean & SD & Rank \\
\hline 23. & $\begin{array}{l}\text { I feel frightened and nervous } \\
\text { before the exam even when } \\
\text { I'm ready. }\end{array}$ & 1.74 & High \\
24. & $\begin{array}{l}\text { During exams I find my self } \\
\text { thinking that the others are } \\
\text { better than me. }\end{array}$ & 1.35 & Medium \\
25. $\quad \begin{array}{l}\text { I feel frightened and nervous } \\
\text { during exams that I forget the } \\
\text { answer. }\end{array}$ & 1.25 & Medium \\
26. $\begin{array}{l}\text { During exams I find myself } \\
\text { thinking of things not related } \\
\text { to the exam. }\end{array}$ & 1.27 & Medium \\
27. I feel very nervous after the \\
exam.
\end{tabular}

The means and standard deviations of students' perceptions to psychological factors are shown in Table 6.

On the other hand, students reported that having a good grade in a test 'always' motivates them to pass the next one (see Table 7). This is supported by Birjandi and Alemi (2010) who argued that past performance on tests affects test anxiety. Also, most students reported that they 'always' feel after finishing the test that they could have done better $(\mathrm{M}=3.84)$. This is natural as one is under stress and once stress disappears, one can think clearly.

Table 7. Means and Standard Deviations of Students' Perceptions to Psychological Factors

\begin{tabular}{lllll}
\hline \multicolumn{1}{l}{ Statement } & Mean & SD & Rank \\
\hline 28. & $\begin{array}{l}\text { During exams I think of the } \\
\text { consequences of failing. }\end{array}$ & 3.03 & 1.39 & Medium \\
29. $\begin{array}{l}\text { If I pass an exam, I feel } \\
\text { confident to pass the next one. }\end{array}$ & 3.89 & 1.01 & High \\
30. $\quad \begin{array}{l}\text { After finishing an exam, I feel } \\
\text { I could have done better. }\end{array}$ & 3.84 & 1.07 & High \\
31. $\quad \begin{array}{l}\text { I feel depressed after the } \\
\text { exam. }\end{array}$ & 2.81 & 1.19 & Medium \\
32. $\begin{array}{l}\text { I try not to think of the exam } \\
\text { once it is done, but I can't. }\end{array}$ & 3.26 & 1.33 & Medium \\
\hline
\end{tabular}

The means and standard deviations of students' perceptions to psychological factors are shown in Table 7.

With respect to 'other factors', results of Table 2 show a medium level $(\mathrm{M}=3.22)$. Some students reported that the time allotted for the test is not always sufficient. Also, most students believed that the test does not always match what they have studied in the course. They believe that grading questions from difficult to easy, rote memorization and student expectation regarding the level of the test affect performance on the test. Students 'always' believe that studying two similar subjects confuses them $(\mathrm{M}=3.84)$. They further reported that some tests depend on rote memorization. 
Table 8. Means and Standard Deviations of Students' Perceptions to Other Factors

\begin{tabular}{|c|c|c|c|c|}
\hline & Statement & Mean & SD & Rank \\
\hline 33. & $\begin{array}{l}\text { Time of the exam is enough to } \\
\text { answer all the questions. }\end{array}$ & 3.46 & 1.10 & Medium \\
\hline 34. & $\begin{array}{l}\text { The exam matches what have } \\
\text { been studied in the course. }\end{array}$ & 3.53 & 0.93 & Medium \\
\hline 35. & $\begin{array}{l}\text { Starting from difficult to } \\
\text { simple questions affects my } \\
\text { grades negatively. }\end{array}$ & 3.10 & 1.17 & Medium \\
\hline 36. & $\begin{array}{l}\text { Rote memorization affects my } \\
\text { grade negatively. }\end{array}$ & 3.28 & 1.11 & Medium \\
\hline 37. & $\begin{array}{l}\text { Thinking that the exam is } \\
\text { easy is the reason behind } \\
\text { my low grades }\end{array}$ & 3.07 & 1.20 & Medium \\
\hline 38. & $\begin{array}{l}\text { Studying two similar subjects } \\
\text { at the same time confuses me. }\end{array}$ & 3.84 & 1.09 & High \\
\hline 39. & $\begin{array}{l}\text { Exam questions depend on } \\
\text { memorization more than } \\
\text { understanding. }\end{array}$ & 3.33 & 1.01 & Medium \\
\hline
\end{tabular}

The means and standard deviations of students' perceptions to other factors are shown in Table 8 .

What is more, students reported that indirect questions or questions that carry more than one idea do not always cause difficulty for them. However, statement 42 in Table 9 recorded a high mean of 3.78 of students' response where students reported 'always' losing concentration when other students ask questions during tests and when assigning a big grade to one question. Finally, most students said they 'always' favored varying questions ( $M=4.03)$.

Table 9. Means and Standard Deviations of Students' Perceptions to Other Factors

\begin{tabular}{llll}
\hline Statement & Mean & SD & Rank \\
\hline 40. & $\begin{array}{l}\text { Writing the question in an } \\
\text { indirect way makes it difficult } \\
\text { to understand it. }\end{array}$ & 1.63 & Medium \\
41. $\begin{array}{l}\text { I feel confused when a } \\
\text { question contains more than } \\
\text { one idea. }\end{array}$ & 1.11 & Medium \\
42. $\quad \begin{array}{l}\text { I lose concentration during the } \\
\text { exam when students ask } \\
\text { questions in a loud voice. }\end{array}$ & 1.78 & High \\
43. I find it difficult to answer \\
$\begin{array}{l}\text { true and false questions. } \\
\text { I panic when a big grade is } \\
\text { put on one question in the } 3.09 \\
\text { exam. }\end{array}$
\end{tabular}

The means and standard deviations of students' perceptions to other factors are shown in Table 9.

According to the second research question related to whether there are differences between EFL female college students' perceptions in terms of age, results showed there were no significant differences as shown in Table 10. This can be justified by the fact that most college students $(80 \%)$ were between 18 and 22 years old where it is hard to find significant differences. However, Aydn et al. (2006) found in a study on Turkish university students between 18 and 23 years old that younger students were more worried than older students. 
Table 10. T-Test of Students' Perceptions of Linguistic, Psychological and Other Factors According to Age

\begin{tabular}{|c|c|c|c|c|c|c|c|}
\hline No & Components & Variables & $\mathrm{N}$ & $\mathrm{M}$ & SD & $\mathrm{T}$ & Sig \\
\hline \multirow{2}{*}{1.} & \multirow{2}{*}{ Linguistic Factors } & $\begin{array}{l}\text { Age } 22 \text { and } \\
\text { less }\end{array}$ & 453 & 2.88 & 0.58 & \multirow{2}{*}{-1.60} & \multirow{2}{*}{0.11} \\
\hline & & $\begin{array}{l}\text { Age } 23 \text { and } \\
\text { more }\end{array}$ & 113 & 2.98 & 0.65 & & \\
\hline \multirow{2}{*}{2.} & \multirow{2}{*}{ Psychological Factors } & $\begin{array}{l}\text { Age } 22 \text { and } \\
\text { less }\end{array}$ & 453 & 3.23 & 0.78 & \multirow{2}{*}{0.89} & \multirow{2}{*}{0.37} \\
\hline & & $\begin{array}{l}\text { Age } 23 \text { and } \\
\text { more }\end{array}$ & 113 & 3.16 & 0.74 & & \\
\hline \multirow{3}{*}{3.} & \multirow{3}{*}{ Other Factors } & $\begin{array}{l}\text { Age } 22 \text { and } \\
\text { less }\end{array}$ & 453 & 3.50 & 0.50 & \multirow{3}{*}{-.023} & \multirow{3}{*}{0.98} \\
\hline & & $\begin{array}{l}\text { Age } 23 \text { and } \\
\text { more }\end{array}$ & 113 & 3.50 & 0.55 & & \\
\hline & & $\begin{array}{l}\text { Age } 23 \text { and } \\
\text { more }\end{array}$ & 113 & 3.09 & .80 & & \\
\hline
\end{tabular}

The T-Test of students' perceptions of the three factors according to age are shown in Table 10.

In relation to the third research question of whether there are differences between EFL college students' perceptions in terms of grade level, results showed significant differences towards 'linguistics factors' for grade one students suggesting that grade one students have more linguistic difficulties than other grade levels (see Table 11). It seems that the higher the grade level, the less difficulties reported. This is in line with Aydn et al. (2006) who reported that first year students are the most worried about tests and their grades are affected negatively. On the other hand, no significant differences were reported for the other two factors. This can be accounted for by the fact that the other factors are general and not specific to English.

Table 11. ANOVA Test for Students' Perceptions to Linguistic, Psychological and Other Factors According to Grade Level

\begin{tabular}{|c|c|c|c|c|c|c|c|}
\hline No & Components & Variables & $\mathrm{N}$ & $\mathrm{M}$ & SD & $\mathrm{F}$ & Sig. \\
\hline \multirow{4}{*}{1.} & \multirow{4}{*}{ Linguistic factors } & year one & 162 & 2.95 & 0.63 & \multirow{4}{*}{2.99} & \multirow{4}{*}{0.031} \\
\hline & & year two & 188 & 2.96 & 0.58 & & \\
\hline & & year three & 143 & 2.87 & 0.60 & & \\
\hline & & year four & 77 & 2.74 & 0.54 & & \\
\hline \multirow{4}{*}{2.} & \multirow{4}{*}{ Psychological factors } & year one & 162 & 3.30 & 0.77 & \multirow{4}{*}{1.292} & \multirow{4}{*}{0.276} \\
\hline & & year tow & 188 & 3.22 & 0.73 & & \\
\hline & & year three & 143 & 3.18 & 0.83 & & \\
\hline & & year four & 77 & 3.11 & 0.77 & & \\
\hline \multirow{4}{*}{3.} & \multirow{4}{*}{ Other factors } & year one & 162 & 3.47 & 0.52 & \multirow{4}{*}{1.276} & \multirow{4}{*}{0.282} \\
\hline & & year tow & 188 & 3.52 & 0.50 & & \\
\hline & & year three & 143 & 3.54 & 0.50 & & \\
\hline & & year four & 77 & 3.42 & 0.55 & & \\
\hline
\end{tabular}

The ANOVA Test for students' perceptions to the three factors as to grade level are shown in Table 11.

Regarding the fourth research question of whether there are differences between EFL female college students' perceptions in terms of nationality, results of Table 12 show significant differences. Kuwaiti students seem to have more difficulties in relation to 'linguistic', 'psychological' and 'other factors'. This might be due to differences in educational background. Most of non-Kuwaitis had their secondary education at private or bilingual schools. These schools care more about students' well being and education. Also, the curricula and the teaching methods in private schools differ from those in government schools. As for social factors, non-Kuwaitis usually come from families 
whose fathers are highly educated. Another possible explanation is that non-Kuwaitis are highly motivated to succeed to be accepted at college once they graduate.

Table 12. T-Test of Students' Perceptions to Linguistic, Psychological and Other Factors According to Nationality

\begin{tabular}{|c|c|c|c|c|c|c|c|}
\hline No & components & Variables & $\mathrm{N}$ & $\mathrm{M}$ & SD & $\mathrm{T}$ & Sig \\
\hline \multirow[b]{2}{*}{1} & \multirow[b]{2}{*}{ Linguistic Factors } & KUWAITI & 426 & 2.96 & 0.59 & \multirow[b]{2}{*}{3.757} & \multirow[b]{2}{*}{0.000} \\
\hline & & $\begin{array}{l}\text { NON- } \\
\text { KUWAITI }\end{array}$ & 139 & 2.74 & 0.60 & & \\
\hline \multirow[b]{2}{*}{2} & \multirow[b]{2}{*}{ Psychological Factors } & KUWAITI & 426 & 3.30 & 0.77 & \multirow[b]{2}{*}{4.835} & \multirow[b]{2}{*}{0.000} \\
\hline & & $\begin{array}{l}\text { NON- } \\
\text { KUWAITI }\end{array}$ & 139 & 2.95 & 0.71 & & \\
\hline \multirow[b]{2}{*}{3} & \multirow[b]{2}{*}{ Other Factors } & KUWAITI & 426 & 3.55 & 0.50 & \multirow[b]{2}{*}{4.113} & \multirow[b]{2}{*}{0.000} \\
\hline & & $\begin{array}{l}\text { NON- } \\
\text { KUWAITI }\end{array}$ & 139 & 3.34 & 0.51 & & \\
\hline
\end{tabular}

The T-Test of students' perceptions to the three factors according to nationality are shown in Table 12 .

In response to the fifth research question of whether there are differences among EFL college students' perceptions in terms of their GPA, results indicate that there are significant differences (see Table 13). Those with lower GPA have more difficulties regarding 'linguistic', 'psychological' and 'other factors' than those with higher GPA. Results also suggest that the lower the GPA, the more difficulties students have.

Table 13. ANOVA Test of Students' Perceptions to Linguistic, Psychological and Other Factors According to GPA Level

\begin{tabular}{|c|c|c|c|c|c|c|c|}
\hline No & Components & Variables GPA & $\mathrm{N}$ & $\mathrm{M}$ & S.D & $\mathrm{F}$ & Sig. \\
\hline \multirow{4}{*}{1} & \multirow{4}{*}{ Linguistic Factors } & $3.67 \&$ more & 43 & 2.44 & 0.64 & \multirow{4}{*}{23.468} & \multirow{4}{*}{.000} \\
\hline & & $3.66-2.67$ & 228 & 2.77 & 0.54 & & \\
\hline & & $2.66-1.67$ & 202 & 3.02 & 0.50 & & \\
\hline & & $1.66 \&$ less & 68 & 3.21 & 0.71 & & \\
\hline \multirow{4}{*}{2} & \multirow{4}{*}{ Psychological Factors } & $3.67 \&$ more & 43 & 2.43 & 0.70 & \multirow{4}{*}{20.125} & \multirow{4}{*}{0.000} \\
\hline & & $3.66-2.67$ & 228 & 2.75 & 0.62 & & \\
\hline & & $2.66-1.67$ & 202 & 3.03 & 0.60 & & \\
\hline & & $1.66 \&$ less & 68 & 3.24 & 0.83 & & \\
\hline \multirow{4}{*}{3} & \multirow{4}{*}{ Other Factors } & $3.67 \&$ more & 43 & 2.83 & 0.79 & \multirow{4}{*}{13.968} & \multirow{4}{*}{0.000} \\
\hline & & $3.66-2.67$ & 228 & 3.05 & 0.75 & & \\
\hline & & $2.66-1.67$ & 202 & 3.32 & 0.71 & & \\
\hline & & $1.66 \&$ less & 68 & 3.58 & 0.83 & & \\
\hline
\end{tabular}

The ANOVA test of students' perceptions to the three factors according to their GPA is shown in Table 13.

In relation to the sixth research questiones about which has the most impact on EFL college students' performance for the three factors, 'linguistic', 'psychological' and 'other', results showed it was a medium effect (Table 2). Nevertheless, students' response suggests that these factors are important and have a considerable effect on students' performance.

Regarding the open-ended question that investigates other reasons students believed were the most important causes behind test difficulty, investigating the topic allowed the researchers to identify what the main causes are from the students' perspective. One of the reasons reported was the huge amount of material tested. In addition, some students showed their dissatisfaction with the time provided in comparison with the amount of questions. As expected, most students seemed to believe that their English proficiency was not up to the college level. They stated that the terminology used in the questions was far from the level of English language education they gained in high school. In this respect, 17 students asked for simplified terminologies that suit their understanding while 24 asked for remedial courses that would help establish a better level of English proficiency. 
While some students felt that constant encouragement from their teachers would ease the process of answering the questions, others blamed their teacher's method of teaching. Some stated that the teacher could not deliver the information clearly, while others felt that the teacher's constant discouragement caused an obstacle in the reception of information. All in all, not being able to understand the topic forced those students to memorize instead of understand the information. Therefore, when the questions required clarification or detail, the students claimed that the information intermingled and they became confused.

Eleven students commented that knowing the type of questions that will be given in a test would make studying and answering the test much easier. Many students protested that after they were given the test, they realized that their method of studying was inappropriate. Some believed that studying for a multiple-choice test would be different from essay questions. In addition, some students believed that the questions, in some cases, were confusing. They claimed that some questions were not appropriately worded and they did not know what is required from those particular questions; others believed the questions were too long, which makes them confusing and very time consuming; and a few felt that when a question included more than one point to discuss, it caused great anxiety. Nonetheless, a few students believed that some of the material they were tested on was not part of the topics covered during the lectures, or was from other chapters that were not supposed to be covered in that particular test.

Finally, many students assumed that the difficulty lied in the fact that, in many cases, they had more than one test during the day. Some students added that they would like to be told of the test date ahead of time to be able to prepare and avoid having another test on the same day, by which, they would be able to have their test in a less tense and more comfortable atmosphere. This idea reflects the fact that some students blamed the psychological aspects on their performance during the test.

Overall, the huge amount of material tested was the biggest difficulty in students' opinion. In addition, it is clear that being non-native speakers of English is the second main cause of difficulty. Students were aware of this fact, and thus, requested remedial English proficiency courses to help them achieve better in the future. The third most important reason of difficulty was the little time provided to answer the questions in comparison with the answers required. Forth came the inappropriate method of teaching. The final factor was the psychological factor of encouragement and tension, which might be relieved with the help of the instructor.

\section{Conclusion}

From the above study, we conclude that there are several factors that affect EFL college students' performance on classroom English tests. Although results showed students' perceptions were at a medium level, they also indicate that these factors play a crucial role in students' academic life. One of the main findings of the study is students need to know the question format before the test. This might be, as Cummins (2000) argued, that academic language is less contextualized and more cognitively demanding. It further suggests students' dependence on rote memorization rather than comprehension.

Results also showed that psychological factors play a crucial role in learning. Students reported worrying before tests, feeling they could have done better afterwards and motivated once they do well. This is consistent with several research findings (Yesilyurt, 2006). However, the open-ended question revealed 'instructors' contribution to the difficulties encountered by students; 'test questions' come next followed by 'vocabulary knowledge', the 'amount and time of the test' and finally the 'testing environment' which need to be taken into consideration when preparing for tests.

However, interpretation of the results of this study should take into account several limitations. The primary limitation stems from the participants. Since the participants are female EFL students at the College of Basic Education (CBE), the results can not be generalized to students in other colleges or to students in primary/ secondary education. Also the results can not be generalized to male students. Second, this study is limited in scope to local classroom EFL tests rather than international standardized tests. Finally, the study used a questionnaire to collect quantitative data. Other data collection instruments would yield more reliable results.

Several recommendations emerge for EFL college students. For example, by finding out that students need to know the question format before the test, instructors should practice different question formats with students by revising previous tests. What is more, faculty can introduce a course titled 'English for Academic Purposes' where students are introduced to academic vocabulary used in their discipline. Likewise, instructors can control test anxiety by revising the assigned material a day before the test and by practicing some test-taking strategies. Also, providing quiet and comfortable environment helps concentration and improves performance. It is hoped that in the future instructors would take students' concerns into consideration when planning and conducting English tests. 


\section{References}

Abidin MJZ; pour-Mohammadi, M \& Alzwari, H. (2012). EFL students' attitudes towards learning English language: the case of Libyan secondary school students. Asian Social Science, 8 (2), 119.

Aboudan, R. (2011). We will learn better only if some things were different: Arab student's voices about their performance in IELTS. The Reading Matrix, 11 (2), 171-204.

Al-Buainain, H. (2006). Students' writing errors in ESL: A case study. A paper presented at The 2nd International AUC OXF Conference on Language and Linguistics, 24-25/3/2006. Cairo, Egypt.

Al-Mutawa, N. (1996). Evaluation of inset course for teachers of English as a foreign language in the primary stage (EFLPS) in Kuwait. The Educational Journal, 10 (39), 15-40.

Al-Nemshan, H. (2013). Weak performance of teachers tied to students taking up tuitions. Al-Seyassah Newspaper.

Aydin, S. (2011). Internet anxiety among foreign language learners. Tech Trends, 55(2), 46-54. http://dx.doi.org/10.1007/s11528-011-0483-y

Aydin, S. (2012). The effects of young EFL learners' perceptions of tests on test anxiety. Education, 40(2), $189-204$.

Aydin, Yavuz, F. \& Yesilyurts, S. (2006). Test anxiety in foreign language learning. Journal of Language and Linguistic Studies, 5(1), 127-137.

Bird, E., \& Welford, G. (1995). The effect of language on the performance of second language students in Science examinations. International Journal of Science Education, 17(3), 389-397. http://dx.doi.org/10.1080/0950069950170309

Birjandi, P., \& Alemi, M. (2010). The impact of test anxiety on test performance among Iranian EFL learners. Broad Research in Artificial Intelligence and Neuroscience (BRAIN), 1(4), 44-58.

Cheung, R. (2012). Teaching for creativity: Examining the beliefs of early childhood teachers and their influence on teaching practices. Australasian Journal of Early Childhood, 37 (3), 34-51.

Coulombe, D. (2000). Anxiety and beliefs of French-as-a-second language learners at the university level. Unpublished Doctoral Dissertation, University of Laval, Quebec, Canada.

Crisp, V. Sweiry, E. Ahmed, A. \& Pollitt, A. (2008). Tales of the expected: The influence of students' expectations on question validity and implications for writing exam questions. Educational Research, 50(1), 95-115. http://dx.doi.org/10.1080/00131880801920445

Cummins, J. (2000). Language, power \& pedagogy. Cleveden, UK: Multilingual Matters. Drew, S. (2001). Perceptions of what helps learn and develop in education. Teaching in Higher Education, 6(3), 309-331.

Filipi, A. (2012). Do questions written in the target language make foreign language listening comprehension tests more difficult? Language Testing, 29(4), 511-532. http://dx.doi.org/10.1177/0265532212441329

Fisher-Hoch, H. Hughes, S. \& Bramley, T. (1997). What makes GCSE examination questions difficult? Outcomes of manipulating difficulty of GCSE questions. Paper presented at the British Educational Research Annual Conference, University of York.

Greene, E.B. (1929). Achievement and confidence on true-false tests of college students. The Journal of Abnormal and Social Psychology, 23(4), 467-478. http://dx.doi.org/10.1037/h0072335

Harrison, S. \& Morgan, R. (2012). Using simplified English to identify potential problems for non-native speakers in the language of engineering examination papers. The Language Learning Journal, 40(1), 113-123. http://dx.doi.org/10.1080/09571736.2012.658230

Ho, Y. (2008). ESL/EFL teachers from overseas-Yes or No? Paper presented at the Annual Meeting of the MWERA Annual Meeting, Western Great Southern Hotel, Columbus, Ohio Online 22/6/2012. Institute of Education Sciences (ies) (2012). WWC Review of the report "Accommodations for English language learner students: The effect of Linguistic Modification of Math Test Item Sets."

Jenkins, W. (2000). The impact of the National Curriculum on secondary school Science Teaching in England and Wales. International Journal of Science Education, $22 \quad$ (3), 325-336. http://dx.doi.org/10.1080/095006900289903

Jing, H. (2005). A diary study of difficulties and constraints in EFL learning. System, 33,609-621. http://dx.doi.org/10.1016/j.system.2005.04.001 
Kanwal, W. \& Khurshid, F. (2012). University students' difficulties in learning English language skills. Language in India: Strength for Today and Bright Hope for Tomorrow, 12(2), 327-337.

Kim, J.H. (2000). Foreign language listening anxiety: A study of Korean students learning English. Unpublished Doctoral Dissertation, University of Texas, Austin.

Korhonen, J. Linnanmaki, K. \& Aunio, P. (2011). Development of academic self-concept and Mathematics in adolescence. Paper presentation in the 13th Biennial Conference of European Association for Research on Learning and Instruction, August 30-September 3, Exeter.

Korhonen, J. Linnanmaki, K. \& Aunio, P. (2012). Language and Mathematical performance: a comparison of lower secondary school students with different level of Mathematical skills. Scandinavian Journal of Educational research, 56(3), 333-344. http://dx.doi.org/10.1080/00313831.2011.599423

Li, M.; Baker, T. \& Marshall, K. (2002). 'Mismatched expectations: a case study of Asian students in New Zealand', Paper presented to the New Zealand Applied Business Education Conference, Christchurch College of Education, Christchurch, 25-27 September.

Malallah, S. (2000). English in an Arabic environment: Current attitudes to English among Kuwait University students. International Journal of Bilingual Education and Bilingualism, 3(1), 19-43. http://dx.doi.org/10.1080/13670050008667698

Murray, J. Riazi, A. \& Cross, J. (2012). Test candidates' attitudes and their relationship to demographic and experiential variables: The case of overseas trained teachers in NSW, Australia. Language Testing, 29(4), 577-595. http://dx.doi.org/10.1177/0265532212440690

Murray, N. L. (2010). Conceptualizing the English language needs of first year university students. The International Journal of the First Year in Higher Education, 1(1), 55-64 http://dx.doi.org/10.5204/intjfyhe.v1i1.19

Onwuegbuzie, A. Baiey, P. \& Daley, C. (2001). Cognitive, affective personality and demographic predictors of FL achievement. The Journal of Educational Research, 94(1), 3-15. http://dx.doi.org/10.1080/00220670009598738

Paris, S.G. Roth, J.L. \& Turner, J.C. (2000). Developing disillusionment: Students' perceptions of academic achievement tests. Issues in Education, 6 (1/2), 17-29.

Ransom, L. Larcombe, W. \& Baik, Ch. (2006). 'Academic success and English language international students' expectations and perceptions, paper presented at the Higher Education Research and Development (HERDSA) International Conference, University of Western Australia 10-13 July.

Saito, Y. Horwitz, E. \& Garza, T. (1999). Foreign language reading anxiety. The Modern Language Journal, 83,202-218. http://dx.doi.org/10.1111/0026-7902.00016

Sarason, I. (1978). The Test Anxiety Scale: Concept and research. In Splelberger, C.D. \& Sarason, I.G. (Eds.) Stress and Anxiety, 5, 185-216.

Shi, L. \& He, L. (2012). Topical knowledge and ESL writing. Language Testing, 29(3), 443-469. http://dx.doi.org/10.1177/0265532212436659

Sweiry, E. Crisp, V. Ahmed, A. \& Pollitt, A. (2002). Tales of the expected: The influence of students' expectations on exam validity. A paper presented at the British Educational Research Association Conference, Exeter.

Teemant, A. (2010). ESL student perspectives on university classroom testing practices. Journal of the Scholarship of teaching and Learning, 10(3), 89-105.

Wait, I.W. \& Gressel, J.W. (2009). Relationship between TOEFL score and academic success for international engineering students. Journal of Engineering Education, 98(4), 389-398. http://dx.doi.org/10.1002/j.2168-9830.2009.tb01035.x

$\mathrm{Xu}, \mathrm{M}$. (1991). The impact of English-language proficiency on international graduate students' perceived academic difficulty. Research in Higher Education, 32, (5), 557-570. http://dx.doi.org/10.1007/BF00992628

Ya-Chin, T. \& Yi-Chih, L. (2012). Test anxiety and foreign language reading anxiety in a Reading-Proficiency Test. Journal of Social Sciences. 8 (1): 95-103.

Zeidner, M. \& Bensoussan, M. (1988). College students' attitudes towards written versus oral tests of English as a foreign language. Language Testing, 5,100-113. http://dx.doi.org/10.1177/026553228800500107

Zheng, S. (2002). Studies and suggestions on English vocabulary teaching and learning. English Language Teaching, $5(5), 129-137$. 